\title{
Elektron milli dövlət: Azərbaycan dilinin qorunmas1 və inkişafı üçün imkan və perspektivlər
}

\author{
Rasim Oliquliyev $^{1}$, Yedgar Cəfərov ${ }^{2}$, Fərhad Yusifov ${ }^{3}$, Ofruz Qurbanova ${ }^{4}$ \\ AMEA İnformasiya Texnologiyaları İnstitutu, Bakı, Azərbaycan \\ Idirector@iit.science.az, ${ }^{2} y e d g a r @ y a n d e x . r u,{ }^{3}$ farhadyusifov@gmail.com, ${ }^{4}$ afruz1961@gmail.com
}

\begin{abstract}
Xülasə - Məqalə elektron milli dövlətdə dilin yeri və roluna həsr edilib. Burada qloballaşmanın milli dillər üçün doğurduğu təhdidlər nəzərdən keçirilir. E-dövlət platformasının dillərin qorunması və inkişafı üçün yaratdığı imkanlara diqqət yönəldilir. Bu platformada dövlət dilinin statusunun təmin olunması üçün həllər irəli sürülür. Eyni zamanda milli azlıqların dillərinin sənədləşdirilməsi üçün təkliflər verilir. E-dövlət platformasında dillə bağlı konkret modullar müəyyənləşdirilir.
\end{abstract}

Açar sözlər: e-dövlət, dövlət dili, milli dil korpusu, dillərin sənədləşdirilməsi, qloballaşma, mədəni müxtəliflik

\section{GİRIS}

Elektron dövlət (e-dövlət) ideyası təcrübədə özünü doğrultduğundan getdikcə daha çox ölkələrdə geniş tətbiq olunmaqdadır. İctimai həyatın ən müxtəlif sahələrinə get-gedə daha dərindən nüfuz edən bu platforma özünün müxtəlif seqmentləri üzrə toplanan zəngin məlumat bazası və bu məlumatların təhlili imkanları ilə cəmiyyətin idarə olunması, ayr1-ayr1 sosial, iqtisadi, siyasi, mədəni və s. meyllərin istiqamətləndirilməsinə, eləcə də kütlənin rəyindən asılı olan bir sıra sosial problemlərin həllinə böyük imkanlar açır. $\mathrm{Bu}$ imkanlardan irəli gələrək hazırda e-dövlətlə bağlı diqqəti çəkən aktual elmi məsələlərdən biri də dövlət dillərinin bu platformadakı yeri və rolunun müəyyənləşdirilməsindən ibarətdir. Eyni zamanda, qloballaşma şəraitində müxtəlif təhlükələrlə üz-üzə qalmış milli dillərin qorunması və inkişafı üçün e-dövlət texnologiyalarının perspektivlərindən istifadə məqsədilə müvafiq həllərin tapılmasıdır.

\section{MÜASIR DÖVRDӘ DÜNYA DİLLORININ VӘZİYYTİ}

Məlum olduğu kimi, sürətlə qloballaşan müasir dünyamızda dil müxtəlifliyinin qorunması xüsusilə mühüm problemə çevrilmişdir [1,2]. Çünki, qloballaşma prosesləri milli informasiya məkanı ətrafindak1 sərhədləri ortadan götürərək dünyaya fəal şəkildə inteqrasiya etmiş cəmiyyətlərə saysız-hesabsız üstünlüklər qazandırdığı kimi, müəyyən təhdidlər də doğurur. Qlobal təhdidlərin böyük bir hissəsi məhz milli dillərə aiddir. Hər bir dil mənsub olduğu xalqın digər milli-mənəvi dəyərləri kimi, daha çox, lokal informasiya məkanının hadisəsi sayıldığından, milli informasiya məkanı təcrid edilmiş vəziyyətdə olduqda bu dəyərlərin, o cümlədən dilin qorunması kifayət qədər asan başa gəlir. Bu zaman cəmiyyət özü həmin məkan xaricindəki informasiya mühitindən nələri götürmək, nələrdən imtina etmək üçün optimal vasitələrə, geniş seçim imkanlarına, ən əsası isə çox böyük zamana malik olur. Amma qloballaşma mühitində bunların heç biri yoxdur. ABŞ, Böyük Britaniya kimi aparıcı ölkələrin güclü iqtisadiyyatına, böyük ənənələrə malik qlobal media resurslarına, zəngin elmi-texnoloji molumat bazasına söykənən ingilis dili çox sürətlə milli dillərin linqvomədəni fəzasına daxil olaraq onları sıxışdırır. Hazırda mövcud internet resurslarının və bu resurslarda mövcud olan informasiyaların təxminən 53\%-i ingilis dilinin payına düşür. Qalan $47 \%$ isə əsasən, rus, alman, yapon, ispan, fransız, çin, portuqal və italyan dilləri kimi aparıcı dillər arasında bölünmüşdür [2]

Məlumat üçün bildirək ki, "hazırda dünyanın 260 ölkəsində 7,5 milyarddan çox insan yaşayır. Onlar ünsiyyət vasitəsi kimi 7 minə yaxın dildən istifadə edirlər. 40 ən çox yayılmış dil dünya əhalisinin 2/3-ni əhatə edir. Dünyadakı mövcud dillərdən yalnız 95-i dövlət dili statusuna malikdir. Bəzi dillər bir neçə dövlətin rəsmi dili kimi qəbul edilib. $\mathrm{O}$ cümlədən ingilis dili 56, fransız dili 29 , orəb dili 24 , ispan dili 20, portuqal dili 8 , alman dili 6 , italyan və rus dilləri 4 , holland və serb dilləri 3 ölkənin dövlət dili statusuna malikdir. Daha 12 dilin hər biri iki ölkədə rəsmi dil kimi işlədilir. Eyni zamanda, 2 və daha artıq dövlət dili olan ölkələr də mövcuddur. Cənubi Afrika Respublikası bu baxımdan daha çox fərqlənir. Belə ki, bu ölkədə 11 rəsmi dövlət dili paralel olaraq işlədilir" [3]. Müasir dünyada dillərin "iyerarxiya"s1 şəkil 1-də verilmişdir.

İngilis dilinin dünyada belə üst mövqe tutmasının əsas generatoru bu dildə elmin, təhsilin, texnologiyaların sürətli inkişafı, başqa sözlə, sivilizasiyanın müasir inkişaf mərhələsində bu dilin elmi-texniki tərəqqinin (internet, fundamental biliklər üzrə əldə edilmiş nailiyyətlər və s.) lokomitivi rolunda çıxış etməsidir. Planetin dil mənzərəsini obyektiv qiymətləndirməyə çalışan UNESCO ekspertlərinin proqnozlarına görə, XXI əsrin sonuna qədər dünyadakı dillərin $50 \%$-dən $90 \%$-ə qədəri tamamilə məhv olub yoxa ç1xa bilər [4].

İlk mərhələdə rəsmi statusu olmayan dillər (tayfa və xalq dilləri) xüsusilə böyük təhlükə qarşısındadır. Tədricən isə bu proses dövlət dillərini də əhatə edəcəkdir. Ona görə də son illər UNESKO və ümumilikdə BMT yoxa çıxmaqda olan dillərin qorunması istiqamətində fəaliyyətini gücləndirmiş, bu 


\section{“Informasiya tohlükasizliyinin aktual multidissiplinar elmi-praktiki problemlori” \\ IV respublika konfransl, 14 dekabr 2018-ci il}

dillərin mühafizəsinin zəruriliyini qlobal səviyyədə aktuallaşdıran bir sıra beynolxalq normativ aktlar, bəyannamələr qəbul olunmuşdur [5].

2001-ci ildə UNECSO dünyada yoxa çıxmaqda olan dillərin atlasını da hazırlamış, atlas sonuncu dəfə 2010-cu ildə

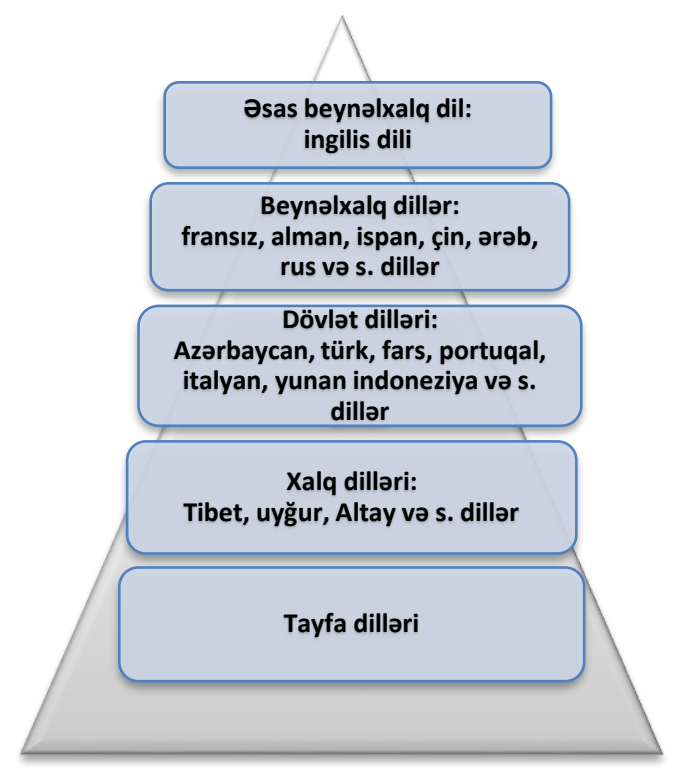

Şəkil 1. Müasir dünya dillərinin “iyerarxiya”s1

UNESKO Baş Konfransının 2003-cü ildə keçirilmiş iclasında isə kiberməkanda ümumi giriş və çoxdillilikdən istifadənin genişləndirilməsi üzrə tövsiyələr təqdim edilmişdir. $\mathrm{Bu}$ tövsiyələr informasiyaya çıxış imkanlarının təmin olunmasında, dünya informasiya şəbəkəsində mədəni müxtəlifliyin və çoxdilliliyin qorunmasında UNESKO-nun rolunun artırılmasını nəzərdə tutur. İnsanlar arasında təkcə ünsiyyət vasitəsi və mədəniyyət vektoru deyil, eyni zamanda dünyagörüşü və dəyərlər süzgəci olan, özünüdərkin bir hissəsi və şəxsin milli identifikasiya vasitəsi kimi çıxış edən dilin qorunmasının vacibliyi irəli sürülür [5].

Avropa Birliyi ölkələrinin ağıllı, dayanıqlı və inklüziv inkişaf istiqamətlərini müəyyən edən "Avropa-2020" strategiyasında da bu ölkələrdə e-dövlət quruculuğu zamanı cəmiyyətin sosial-mədəni, dil müxtəlifliyinin nəzərə alınmas1 və qorunmasına səy göstərilməsi əsas baza prinsiplərindən biri kimi öz əksini tapmışdır [7].

Göründüyü kimi, beynəlxalq normativ sənədlərin tövsiyələrinə və qabaqcil ölkələrin e-dövlət quruculuğu təcrübəsinə əsaslanaraq elektron milli dövlətdə dilə münasibətdə iki təsəvvür formalaşdırmaq olar. Birinci təsəvvürə görə, e-dövlət xidmətlərinin yaradılmasında dil müxtəlifliyinin qorunması çox aktualdır. Dövlət idarəçiliyi sisteminin yenidən təşkili və e-dövlət quruculuğu prosesində digər zəruri şərtlərlə yanaşı, sırf dillə bağlı bu məqamlar mütləq nəzərə alınmalıdır: çoxdilliliyə əsasaslanan kommunikasiya vasitələrindən geniş istifadə; xidmətlərin
Norveç hökumətinin dəstəyi ilə yenilənmişdir. 2500-dən çox dilin öz əksini tapdığı atlasa Azərbaycanda da yoxa çıxmaq təhlükəsinin müxtəlif səviyyələrində olan 11 dil daxil edilmişdir. Bunlar buduq, saxur, lahıc, xınalıq, kilit, udin, qrız, rutul, tat, lozgi vo talış dilləridir [6].

beynəlxalq standartlara uyğunlaşdırılması və çoxdilliliyin dəstəklənməsi; dil, din, milli mənsubiyyət, təhsil səviyyəsi, bacarıqlar, fiziki qabiliyyətlər, yaşayış yeri və s. amillərdən asılı olmayaraq elektron xidmətlərin hər kəs üçün əlçatanlığı.

İkinci təssəvvür isə e-dövlətin yaratdığ 1 geniş imkanlardan istifadə edərək ölkə ərazisindəki etnik qrupların dillərinin mədəni sərvət kimi mühafizəsi, həmçinin ölkənin Konstitusiya ilə təsbit edilmiş əsas dövlət dilinin bu vasitə ilə qlobal təhdidlərdən qorunması, onun dayanıqlı inkişafının təmin olunmasidır.

Azərbaycan Respublikası Konstitusiyasının 21-ci maddəsinin I hissəsinə əsasən, Azərbaycan Respublikasının dövlət dili Azərbaycan dilidir. Bu dil dövlət dili kimi ölkənin siyasi, ictimai, iqtisadi, elmi və mədəni həyatının bütün sahələrində işlədilir [8]. Azərbaycan Respublikasında dövlət hakimiyyəti və yerli özünüidarəetmə orqanlarında, dövlət qurumlarında, siyasi partiyalarda, qeyri-hökumət təşkilatlarında (ictimai birlik və fondlarda), həmkarlar təşkilatlarında, digər hüquqi şəxslərdə, onların nümayəndəliklərində və filiallarında, idarələrdə dövlət dilinin tətbiqi ilə bağlı fəaliyyət "Azərbaycan Respublikasında dövlət dili haqqında" Qanuna uyğun olaraq həyata keçirilir, o cümlədən kargüzarlıq işləri dövlət dilində aparılır [9]. Konstitusiyamızın 21-ci maddəsinin II hissəsinə görə, Azərbaycan Respublikası əhalinin danışdığı başqa dillərin sərbəst işlədilməsini və inkişafını təmin edir [8].

E-dövlət mühiti isə elə bir həllin tapılmasına imkan verir ki, onunla həm dövlət dilinin Konstitusiya ilə təsbit edilmiş statusunu və təbii inkişafinı, həm respublikadakı milli azlıqların öz dillərindən istifadə ilə bağlı hüquqlarını, həm də ölkə ərazisində müvəqqəti yaşayan əcnəbilərin e-xidmətlərdən maneəsiz istifadəsini təmin etmək mümkün olsun.

Bu sahədə əsas perspektiv layihə e-dövlət platformasında milli dillərin sistem arxitekturasının qurulmasıdır. Belə bir arxitektura hesabına milli dillərin e-dövlət platformasının üzvi tərkib hissəsinə çevrilməsi, bu texniki orqanizmdə özünə yer tutması qloballaşma dövründə dillərin qorunması və inkişafina böyük töhfə verəcəkdir.

\section{ELEKTRON MILLİ DÖVLӘTDӘ DİLİN ARXITEKTURASI}

Milli dillərin öz sistem arxitekturası ilə e-dövlətin üzvi tərkib hissəsinə çevrilməsi və bu platformanın bütün seqmentləri üzrə təbii inkişafının təmin olunmasından ötrü yeni metodlar, alqoritmlər, yanaşmalar işlənməli, bir sıra tətbiqlər hazırlanmalıdır. Bu məqsədə çatmaq üçün aşağıdakı məsələlərin həlli zəruri sayılır:

- e-dövlətin bütün vətəndaşlar və ölkədə müvəqqəti yaşayan əcnəbilər üçün əlçatanlığı məqsədilə 


\section{“Informasiya tohlükasizliyinin aktual multidissiplinar elmi-praktiki problemlori” \\ IV respublika konfransl, 14 dekabr 2018-ci il}

lokallaşdırma (dövlət dilindən istifadə) və qloballaşdırma (əsas xarici dillərdən istifadə) problemlərinin həlli;

- ölkə ərazisində yaşayan milli azlıqların dillərinin sənədləşdirilməsi (language documentation) üçün edövlət platformasının imkanlarından istifadə;

- e-dövlət sistemində toplanmış böyük həcmdə verilənlərin təhlili ilə ölkədəki mövcud dil situasiyasının mütəmadi qiymətləndirilməsi;

- e-dövlət mühitində, kütləvi-informasiya vasitələrində, sosial mediada və s. dildən istifadənin intellektual analizi metodlarının işlənməsi və əks-əlaqə mexanizmlərinin tətbiqi;

- e-dövlət sistemində dilin sanitariyas1, orfoqrafiya, orfoepiya, transliterasiya, terminologiya, dialektologiya məsələləri, adlar və soyadlar, vulqarizmlər, marka adları, dil sənayesi xidmətləri (maşın tərcüməsi, nitqin tanınması, süni intellekt, dilöyrənmə və dil biliyi səviyyəsini qiymətləndirmə və s.), Dilin Milli Korpusu və s. bu kimi modulların formalaşdırılması;

- milli domen adlarının tətbiqi və çoxdilli internetin dəstəklənməsi üçün texniki tədbirlərin həyata keçirilməsi;

- qloballaşma şəraitində milli dillərin qorunması və inkişafının təmin olunmasından ötrü təklif edilən metod və alqoritmlərin korporativ şəbəkələrdə tətbiqi.

Şəkil 2 e-dövlət mühitində Azərbaycan dilinin qorunması sisteminin konseptual modelini əks etdirir. Belə bir modelin tətbiqi e-dövlət bazasında dilin müxtəlif səviyyələri üzrə material bazasının toplanmasına, təhlilinə, qiymətləndirilməsinə və onlardan məqsədyönlü şəkildə istifadəyə şərait yaradacaqdır.

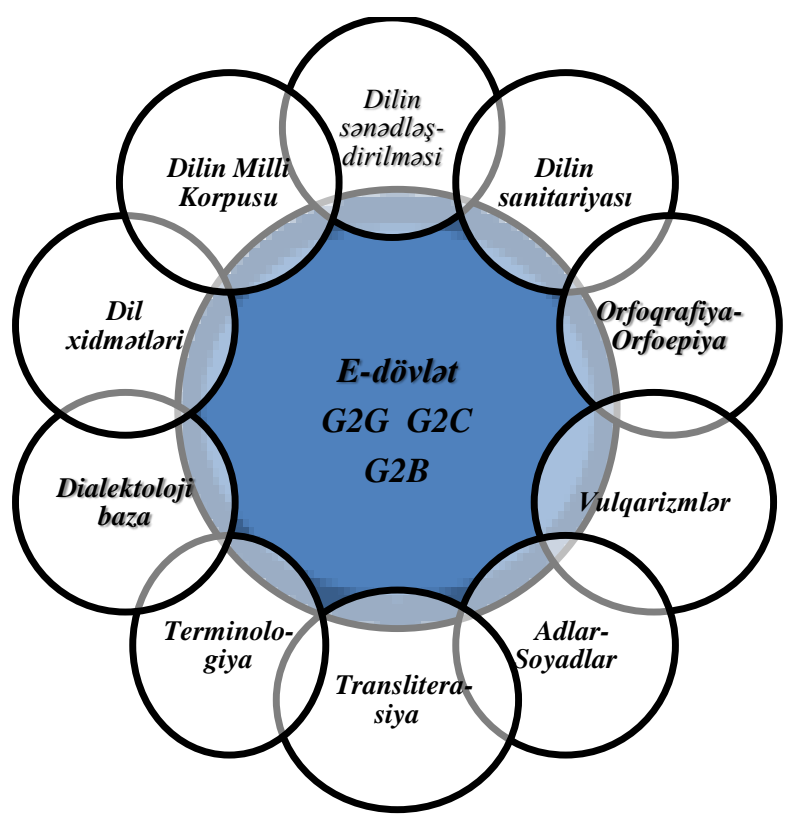

Şəkil 2. E-dövlət mühitində Azərbaycan dilinin qorunmasl sisteminin konseptual modeli

$\mathrm{Bu}$ modeli təşkil edən modullar haqqında q1sa məlumat aşağıda verilmişdir:
Dillərin sənədləşdirilməsi modulu (language documentation): Dillərin sənədləşdirilməsi dilçiliyin yeni bir elmi istiqamətidir. $\mathrm{O}$, sahəvi linqvistika ilə əlaqəli şəkildə az tədqiq edilmiş dilləri özünün təbii mühiti ilə birgə öyrənir. Dillərin sənədləşdirilməsinin əsas predmeti milli azlıqların dillərinə aid ilkin materialların yı ğılaraq vahid elektron mənbədə toplanmasıdır. Dilin sənədləşdirilməsi deyərkən, dil materiallarının uzunmüddətli və çoxməqsədli fiksasiyası başa düşülür [10].

Dilin daşıyıcıları ilə sıx əlaqələr, onların bu işə cəlb olunması böyük səmərə verdiyindən yerli icmaları, milli mədəniyyət mərkəzlərini, bələdiyyələri, təhsil müəssisələrini və s. bu prosesə cəlb etməklə e-dövlət mühitində dillərin sənədləşdirilməsi üzrə çox uğurlu layihələr həyata keçirmək mümkündür.

Dilin sanitariyası modulu: $B u$ gün insanlar arasında ünsiyyət proseslərinin virtuallaşması dildə yeni meyllər yaradır. Bu meyllərin mühüm bir qisminin müasir həyatımızın ayrılmaz tərkib hissəsinə çevrilmiş sosial şəbəkə ünsiyyətində ortaya çıxdığını görürük. Bunun ən səciyyəvi xüsusiyyətləri şifahi nitqdə olduğu kimi sosial şəbəkə mühitində də dil normalarından kənarlaşma, fikrin yığcam ifadəsinə meyl, simvolların, şəkillərin söz, cümlə və mətnləri əvəz etməsi, bir sıra yeni sözlərin yaranması, mövcud sözlərin yeni məna çalarları qazanması və s. bu kimi tendensiyalardır [11].

E-dövlətdə isə dilin sanitariyası ilə bağlı xüsusi modul formalaşdırılmalıdır. Burada dilin distant tədrisi layihələri həyata keçirilməli, insanların yazı və nitq qabiliyyətinin inkişafina yönəlmiş videodərslər hazırlanaraq hər kəsin istifadəsinə verilməlidir. Virtual kommunikasiyalarda, efirdə dil normalarının pozulması hallarının qarşısını almaqdan ötrü şəbəkələrə inteqrasiya edilmiş elektron redaktə, korrektə, mətnyaratma proqramlarının tətbiqi də bu modulun tərkib hissələri kimi nəzərdə tutulur. Dilin sanitariyasına aid modulun köməyi ilə elektron kütləvi informasiya vasitələrində - televiziyalarda, radioda dil normalarından kənarlaşma hallarının dəqiq monitorinqi və pozuntu hallarının aradan qaldırılması da mümkün olacaqdır.

Orfoqrafiya və Orfoepiya modulu: E-dövlət platformasının yaratdığ 1 digər əhəmiyyətli imkanlardan biri də dilin orfoqrafik və orfoepik normalarının tənzimlənməsidir. $\mathrm{Bu}$ sahədəki mövcud problemlərin aradan qaldırılmasından ötrü e-dövlətdə dilin orfoqrafiyası və orfoepiyası ilə bağlı xüsusi bir modul formalaşdırıla bilər. $\mathrm{Bu}$ modul müvafiq standartlar əsasında müəyyən edilmiş orfoqrafiya və orfoepiya qaydalarına hamiliqla riayət olunmasına nəzarəti təmin edəcəkdir.

Vulqarizmlər modulu: İnformasiyalı cəmiyyətdə etik davranış normalarının qorunması, eyni zamanda informasiya təhlükəsizliyi baxımından kifayət qədər mühüm əhəmiyyət kəsb edən məsələlərdən biri də virtual məkanda vulqarizmlərdən istifadə, bu dil vahidlərinin doğurduğu problemlər və onların həlli yollarının tapılmasıdır. Söz süzgəclərinin yaradılması və istifadəsi təcrübəsinə əsaslanaraq e-dövlət platformasında qlobal vulqarizm bazasının 


\section{“Informasiya tohlükosizliyinin aktual multidissiplinar elmi-praktiki problemlori” IV respublika konfransl, 14 dekabr 2018-ci il}

yaradılması elektron mühitdə vulqarizmlərə qarşı uğurlu mübarizə üsulu ola bilər.

Adlar-Soyadlar modulu: Adlar, ata adları və soyadlar elektron idarəetmə mühitində mühüm funksiya yerinə yetirir. Ona görə də xüsusi adlarla bağlı bir sıra məsələlərin həlli, o cümlədən adların modelləşdirilməsi, vahid adlandırma standartının formalaşdırılması, ad komponentlərinin müəyyənləşdirilməsi, adlardakı təhrif tiplərinin aradan qaldırılması, adların elektron bazalarının yaradılması və onlardan istifadə mexanizmlərinin işlənib hazırlanması, adların transliterasiyası normalarının dəqiqləşdirilməsi, adların orfoqrafiyası qaydalarının nizama salınması və s. e-dövlət sistemi üçün xüsusi əhəmiyyət kəsb edir [12]. Bütün bunlar isə sistemdə belə bir modulun yaradılması hesabına təmin oluna bilər.

Transliterasiya modulu: Hazırda dilimizin qəbul olunmuş vahid transliterasiya qaydaları mövcud olmadığından bəzi anlaşılmazlıqlar meydana çıxır. Azərbaycan dilində danışıb ünsiyyət quran insanlar, xüsusilə, yeniyetmə və gənclər virtual ünsiyyət zamanı Azərbaycan sözlərini bir deyil, bir neçə variantda yazırlar. $\mathrm{Bu}$ cür problemlər latın hərflərindən istifadənin vahid sistemini qəbul etmiş Gürcüstan, Rusiya, İsrail, Çin və ya Yaponiya kimi ölkələrdə mövcud deyil. Nəzərə almaq lazımdır ki, latın qrafikasından istifadə heç də Azərbaycan əlifbasından imtinaya dəlalət etmir. Edövlətdə vahid standartın tətbiqi latın əlifbasında yazı və oxumanı asanlaşdıracaq, beləliklə, e-xidmətlərdən istifadə insanlar üçün daha rahat və əlçatan olacaqdır [13]. E-dövlətdə əlifba və transliterasiya ilə bağlı problemlərin həlli üçün aşağıdakı tədbirlərin həyata keçirilməsi böyük səmərə verərdi:

- Azərbaycan dili qrafikasının latın qrafikasına transliterasiya standartının qəbulu və tətbiqi;

Azərbaycan əlifbasını latın əlifbasına və əksinə avtomatik transliterasiya edən proqramların yaradılması;

- Qarşılıqlı transliterasiya səhvləri korrektorunun (spell check) totbiq olunmas1.

Milli Terminoloji İnformasiya modulu: Elmi, texniki və iqtisadi fəaliyyətin yüksək səviyyədə təşkili dəqiq işlənmiş terminologiyadan əhəmiyyətli dərəcədə asılıdır. Ona görə də dil siyasətinin mühüm hissəsi kimi terminologiyanın elminəzəri və praktiki problemlərinə xüsusi diqqət yetirilməsi vacibdir. Bu zərurəti nəzərə alaraq, AMEA-nın İnformasiya Texnologiyaları İnstitutu Milli Terminoloji İnformasiya Sisteminin (MTIS) konsepsiyası və veb-portalını hazırlamışdır $[14,15]$. Bu sistemin köməyi ilə terminoloji problemlərin həllində, terminlərin ictimai müzakirəsi və ekspertizası işlərində marağı olan hər kəs iştirak edə bilər. Bu imkan ölkəmizdə vətəndaş terminologiyasının formalaşması üçün əhəmiyyətlidir. Sistem vətəndaşlara e-terminoloji xidmətlər göstərməklə yanaş1, ölkədə terminologiya fəaliyyətinin təkmilləşdirilməsinə töhfə verəcək. Amma sistemin səmərəli fəaliyyətinin təmin olunması üçün onun müntəzəm yenilənməsi, interaktivliyinin təmin olunması mühüm şərtdir.

\footnotetext{
Dialektologiya modulu: Dialektoloji atlasların yaradılması prosesində kompüter və şəbəkə texnologiyalarından istifadə müasir dilçiliyin kifayət qədər
}

perspektivli istiqamətlərindən sayılır. Hazırda bu metoddan dünya və o cümlədən rus dilçiliyində geniş istifadə olunmaqdadır. AMEA-nın Nəsimi adına Dilçilik İnstitutunda, eləcə də digər elm və tədris müəssisələrində dialektlərimizin öyrənilməsi ilə bağlı əhatəli tədqiqatlar aparılıb [16, 17]. Bu sahədə böyük bir məktəb formalaşıb. Dilçilik coğrafiyası, dialekt leksikası, etnolinqvistika, regional onomastika və $\mathrm{s}$. sahələrində bir çox məsələlər öz elmi həllini tapıb və Azərbaycanın bir çox regionlarının dialektoloji atlasları hazırlanıb. Müasir dövrdə isə uzun onilliklər ərzində toplanmış dialekt materiallarının rəqəmli məlumat bazalarının yaradılmasına, bu məlumatların virtual xəritələr üzrə qruplaşdırılmasına, eyni zamanda burada mətn məlumatları ilə yanaşı, audiovizual materialların öz əksini tapmasına ehtiyac vardır.

Marka adları modulu: E-dövlətdə marka adları ilə bağlı problemləri aktuallaşdıran əsas məsələ isə onların sahibkarlıq fəaliyyətinin mühüm tərkib hissəsi kimi çıxış etməsi, hüquqi qeydiyyatı, əmtəə nişanları üzərində mülkiyyət hüquqlarının qanunvericiliklə qorunması, habelə onların son onillikdə effektiv bir fəaliyyət sahəsi kimi formalaşmış rəqəmsal marketinqdəki yeri və roludur. Bütün bunlar bir çox ölkələrdə olduğu kimi Azərbaycanda da e-dövlətin tərkibində marka adlarının elektron analizi xidmətinin yaradılması zərurətini aktuallaşdırır. Azərbaycanda belə bir sistemin yaradıcısı və tənzimləyicisi qismində müvafiq elmi qurumlarla müştərək şəkildə Azərbaycan Respublikasının Oqli Mülkiyyət Agentliyi çıxış edə bilər.

Dil xidmətləri (dil sənayesi) modulu: Dil sənayesinin əsasında bu sahədə İKT-nin uğurlu tətbiqi dayanır. Bu sferada tədris, tərcümə, lokallaşdırma və digər xidmətlərin göstərilməsi, eyni zamanda, qlobal informasiya cəmiyyətinin formalaşmasına və inkişafına xidmət edir. Azərbaycanda da dil sənayesinin inkişafi üçün böyük potensial mövcuddur. Ölkədə dil sənayesini stimullaşdıran əsas amillər xarici investisiyalar, turizm sektorunun sürətlə inkişafi, tərcümə biznesinin əhəmiyyətli bazar payı qazanmasıdır [18]. Azərbaycan televiziyalarında dublyaj redaksiyalarının fəaliyyəti, müvafiq dövlət qurumlarının, çoxsaylı biznes subyektlərinin vətəndaşlarla, müştərilərlə Qaynar xətt, Məlumat Mərkəzi formatında interaktiv kommunikasiyaları, xarici dillərin öyrənilməsinə maraq dil sənayesinin potensialını gücləndirir. Eyni zamanda Azərbaycan dilinin öyrənilməsinə böyük marağı nəzərə alaraq Azərbaycan Respublikasının Prezidenti 7 iyul 2018-ci il tarixində "Azərbaycan dilinin elektron məkanda daha geniş istifadəsinin təmin edilməsi ilə bağlı bir sıra tədbirlər haqqında" Sərəncam və 1 noyabr 2018-ci il tarixində "Azərbaycan dilinin saflığının qorunmas1 və dövlət dilindən istifadənin daha da təkmilləşdirilməsi ilə bağlı tədbirlər haqqında" Fərman imzalamışdır [19, 20].

Ölkədə dil sənayesini məqsədyönlü şəkildə inkişaf etdirmək üçün kompleks elmi-praktik tədqiqatların həyata keçirilməsi, mövcud problemlərin, müvafiq hüquqi və iqtisadi situasiyanın dərindən öyrənilməsi, bu sahənin inkişafi üçün konseptual baxışların formalaşdırılması, hüquqi, iqtisadi, təşkilati, kadr hazırlığı və s. sahələri əhatə edən müvafiq 


\section{“Informasiya tohlükasizliyinin aktual multidissiplinar elmi-praktiki problemlori” \\ IV respublika konfransl, 14 dekabr 2018-ci il}

ekosistemin formalaşdırılması vacibdir. $\mathrm{Bu}$ məsələlərin edövlət platformasında nəzərə alınması, dillə bağlı exidmətlərin göstərilməsi ölkəmizdə dil sənayesinin inkişafına təkan verəcəkdir.

Milli Dil Korpusu modulu: Milli Dil Korpusları elmi araşdırmalar və dilin tədrisi prosesinin optimallaşdırılması məqsədilə yaradılır. Korpus dili bütün janr və üslub müxtəliflikləri, dialektləri və peşə leksikası ilə və ya onun mövcudluğunun bütün mərhələlərində təmsil edir. Hazırda dünyanın bir çox ölkələrində dünyanın aparıcı dilləri üçün milli korpus tərtib olunmuşdur. Dünyanın ən çox tanınmış və nümunə kimi qiymətləndirilən korpusu Britaniya Milli Korpusu hesab edilir [21]. Slavyan dilləri ailəsində isə rus və çex dillərinin milli korpusları xüsusilə seçilir. Bu mütərəqqi təcrübələrdən faydalanmaqla Azərbaycan dilinin Milli Korpusunun yaradılmas1 və e-dövlətin tərkib hissəsinə çevrilməsi zəruridir. E-dövlət mühitində dilin müxtəlif səviyyələr üzrə texniki inteqrasiyası Milli Dil Korpusunun formalaşdırılması və zaman-zaman inkişafı üçün geniş imkanlar yaradır.

\section{NəTİCə}

Ümumiyyətlə, İnternet mühitində dilin qorunması və inkişafı üsulları ilə bağlı müxtəlif ideyalar, yanaşmalar vardır. Qloballaşma prosesində dili təhlükə altında qoyan bir çox amillər mövcuddur və bu amillərin hər birinin ayrı-ayrılıqda nəzarətdə saxlanılması hesabına dili qorumaq çox çətindir. Yalnız dilin e-dövlət platformasının üzvi tərkib hissəsinə çevrilməsi, e-Azərbaycan seqmentində linqvistik texnologiyaların istifadəsi ilə müxtəlif e-xidmətlərin göstərilməsi vo bu sistemlərin davamlı şəkildə təkmilləşdirilməsi hesabına ana dilimizi qorumaq və inkişaf etdirmək mümkündür.

\section{ӘDӘBIYYAT}

[1] P.Mittal, A.Kaur, "E-Governance - A challenge for India", International Journal of Advanced Research in Computer Engineering \& Technology (IJARCET), Vol. 2, Issue 3, 2013, 1196-1199

[2] World Wide Web Technology Surveys. https://w3techs.com/technologies/overview/content_language/all

[3] R.M.Oliquliyev, R.Ş.Mahmudov, "Dil sənayesi: imkanlar, perspektivlər və problemlər", // İnformasiya cəmiyyəti problemləri, 2018, № 1, səh. 3-26.

[4] Language Vitality and Endangerment. UNESCO Ad Hoc Expert Group on Endangered Languages, International Expert Meeting on UNESCO Programme Safeguarding of Endangered Languages, Paris, 10-12 March 2003, $27 \quad$ p. http://www.unesco.org/new/fileadmin/MULTIMEDIA/HQ/CLT/p df/Language_vitality_and_endangerment_EN.pdf

[5] Деятельность ЮНЕСКО по защите исчезающих языков. http://lingsib.iea.ras.ru/ru/articles/smeets.shtml

[6] Atlas of the World's Languages in Danger. UNESCO, 2011, 20 p. http://unesdoc.unesco.org/images/0019/001924/192416e.pdf

[7] EUROPE 2020. A European strategy for smart, sustainable and inclusive growth. Brussels, 3.3.2010, 37 p.
http://ec.europa.eu/eu2020/pdf/COMPLET\%20EN\%20BARROSO $\% 20 \% 20 \% 20007 \% 20-\% 20$ Europe $\% 202020 \% 20$

$\% 20$ EN\%20version.pdf

[8] Azərbaycan Respublikasının Konstitusiyası. http://www.eqanun.az/framework/897

[9] "Azərbaycan Respublikasında dövlət dili haqqında" Qanun. http://mfa.gov.az/files/file/8.pdf

[10] J.Gippert, N.P.Himmelmann, U.Mosel, "Essentials of Language Documentation", 2006, Berlin, New York: Mouton de Gruyter, $437 \mathrm{p}$.

[11] J.D.Jimma, "Language of social media. Examination of English as a Lingua Franca in social media", University of Iceland, School of Humanities, Department of English, 2017, 32 p. https://skemman.is/bitstream/1946/27228/1/Language $\% 20$ of $\% 20$ so cial\%20media\%2C\%20J\%C3\%B3hann\%20Dan\%C3\%ADel\%20Ji mma.pdf

[12] “Adlar və Soyadlar" Dövlət İnformasiya Sisteminin yaradılması Konsepsiyası. Bakı, "İnformasiya Texnologiyaları" nəşriyyatı, Ekspress-İnformasiya, 2010, 49 s.

[13] S.V.Məmmədzadə, "Verilənlərin emalında transliterasiya və transkripsiyanın rolu", // İnformasiya cəmiyyəti problemləri, 2018, №1, s. 115-122.

[14] R.M.Alguliyev, A.M.Gurbanova, "The Conceptual Foundations of National Terminological Information System", // International Journal of Education and Management Engineering (IJEME), 2018, Vol. 8, No. 4, pp.19-30.

[15] www.terminologiya.az

[16] http://dialekt.vspu.ru/

[17] M. Mahmudov, "Kompüter dilçiliyi". Bakı, "Elm və təhsil" nəşriyyatı, 2013, $356 \mathrm{~s}$.

[18] R.M.Oliquliyev, R.Ş.Mahmudov, "Dil sənayesi: imkanlar, perspektivlər və problemlər", // İnformasiya cəmiyyəti problemləri, 2018, №1, s. 3-26

[19] http://e-qanun.az/framework/39503

[20] https://president.az/articles/30563

[21] http://www.natcorp.ox.ac.uk/

\section{ELECTRONIC NATIONAL GOVERNMENT: PROTECTION OF THE AZERBAIJANI LANGUAGE, OPPORTUNITIES AND PROSPECTS FOR ITS DEVELOPMENT}

\author{
Rasim Alguliyev ${ }^{1}$, Yedgar Jafarov², Farhad Yusiphov ${ }^{3}$, Afruz \\ Gurbanova $^{4}$ \\ 1,2,3,4 Institute of Information Technology of ANAS, \\ Baku, Azerbaijan \\ Idirector@iit.science.az, ${ }^{2} y e d g a r @ y a n d e x . r u$, \\ ${ }^{3}$ farhadyusifov@gmail.com, ${ }^{4}$ afruz1961@gmail.com
}

Abstract - The article is devoted to the role and place of language in e-national government. It addresses the threats of globalization to the national languages. The article also touches upon the opportunities of e-government for the protection and development of languages. The article puts forward solutions to ensure the status of the state language on this platform. Moreover, it presents proposals for the documentation of the languages of national minorities. It identifies specific language-related modules for e-government platform.

Keywords - e-government, official language, national language, language documentation, globalization, cultural diversity 